\title{
Invisibilidade social e reação popular em uma favela da Baixada Fluminense: o caso Nova Jerusalém ${ }^{12}$
}

Linderval Augusto Monteiro ${ }^{3}$

Lançando mão das metodologias da chamada história oral, o artigo apresenta uma revolta ocorrida em uma minúscula favela situada na periferia do município fluminense de Duque de Caxias a partir do justiçamento de dois traficantes. Em seguida, procede-se à análise do contexto em que ocorreu a revolta popular, discutindo-se, finalmente, as formas como a região da Baixada Fluminense desenvolveu-se demograficamente nas últimas décadas e como as formas eleitas por sua população de resolução de problemas forjaram o surgimento de um novo modelo de liderança política local.

Palavras-chave: Invisibilidade Social - Violência Urbana - Cidadania

Social invisibility and popular reaction in a slum of Baixada Fluminense: the case of Nova Jerusalém

Making use of the methodologies of so-called oral history, the article deals with a revolt which occurred in a small slum located on the periphery of the outlying Rio de Janeiro suburb of Duque de Caxias following the trial of two drug dealers. It then proceeds to analyse the context in which the popular revolt took place, and finally discusses the ways

\footnotetext{
${ }^{1}$ Artigo recebido e aprovado para publicação em janeiro de 2011.

${ }^{2}$ Este artigo constitui-se em uma versão bastante modificada do último capítulo de minha tese de doutoramento (Retratos em movimento: vida política, dinamismo popular e cidadania na Baixada Fluminense), orientada pela professora doutora Marieta de Moraes Ferreira, financiada pela Capes e defendida em maio de 2007 no PPGHIS da UFRJ.

${ }^{3}$ Professor-adjunto da Universidade Federal da Grande Dourados (UFGD). E-mail: lindervalmonteiro@ufgd.edu.br
} 
in which the region of Baixada Fluminense has developed demographically in recent decades, and how the means of resolving problems chosen by the local population resulted in the appearance of a new model of local political leadership.

Keywords: Social invisibility - Urban violence - Citizenship.

Invisibilité sociale et réaction populaire dans un bidonville de Baixada Fluminense: le cas de Nova Jerusalém

Disposant de méthodologies rattachées à l'histoire orale, l'article présente une révolte dans un minuscule bidonville situé dans la banlieue de la commune de Duque de Caxias, à partir du règlement de comptes de deux trafiquants. Ensuite, on procède à l'analyse du contexte où se produisit la révolte populaire et finalement où se discutent la façon dont la région de Baixada Fluminense s'est développée démographiquement pendant les dernières décennies et comment les formes de résolution de problème élues par leur population a forgé l'émergence d'un nouveau modèle de présidence politique sociale.

Mots-clés: Invisibilité sociale - Violence urbaine - Citoyenneté.

No dia 6 de julho de 1999, os policiais militares do 15ํㅡㄹ Batalhão, localizado em Duque de Caxias, surpreenderam-se ao receberem telefonemas anônimos informando que os moradores da favela de Nova Jerusalém, armados com paus, pedras, ferramentas de trabalho, como foices, enxadas e cavadeiras, expulsaram dali um grupo de bandidos.

Responsável pelo policiamento de boa parte da Baixada Fluminense, o Batalhão tem como área de atuação uma grande quantidade de favelas e uma miríade de bairros populares com elevados índices de violência, sendo inédito para os policiais deslocarem-se até uma favela para verificar a veracidade de uma informação daquele tipo. Aquilo, na visão deles, nem sequer constituía uma verdadeira ocorrência. O usual é a "população carente" compartilhar suas vidas com os bandidos, o que faz com que policiais entendam ser o "malandro" e o "trabalhador" duas faces de uma mesma moeda. Aliás, acreditando-se em depoimentos de praças e oficiais lotados no Batalhão de Duque de Caxias, "a lei do silêncio" é imposta muito mais pela "amizade com a bandidagem", por uma espécie de "solidariedade entre vizinhos de infortúnio", do que pelo medo de alguma repressão "marginal". Exceções sempre existem, porém na maior parte dos casos bandidos e "populares" não se estranham, sendo sutis as diferenças entre eles. Isso por- 
que, em bairros carentes e em favelas, o crime não é unicamente um meio de vida. Trata-se de um "estilo". Espero os policiais não quererem dizer com isso que o crime é algo pelo qual se opta. As pessoas são "transformadas em bandidos" invariavelmente respondendo a necessidades materiais extremas, porém passam a se constituir em algo distintivo o uso das armas e a possibilidade de alcançar poder e afirmar-se através da violência. No final de tudo, o crime, ou a vida criminosa, passa a ser "algo invejado", e por isso manifestações populares são comuns quando os principais "meliantes" são mortos ou por policiais ou por "malandros estrangeiros".

Mas o fato é que os bandidos daquela favela, ao contrário do que era considerado normal, "atormentavam" a vida de todos os moradores com atividades como cobranças de "pedágios" para a entrada e saída do local, comissões pela venda de barracos, criação de "taxas" destinadas à compra de munições pelo bando, expulsão de moradores que se negassem a auxiliar aqueles elementos não desejados, e também organizavam um serviço de venda de drogas, providenciando com certa frequência o incêndio de barracos e a eliminação de moradores aparentados com crianças ou adolescentes que se recusassem a manter relações sexuais com os bandidos.

Para alguns policiais, o fato detonante daquela "revolta inédita" era provavelmente o assassinato de uma das moradoras da favela e de um de seus filhos. Os dois foram mortos por ordem de alguém que ocupava o posto de chefe do bando desde o ano 1998, quando expulsara o antigo "dono do lugar", ao qual era subordinado, passando a impor "o terror". A troca de "dono" na favela revelara-se um verdadeiro desastre. Não que o antigo chefe dos bandidos fosse um aliado dos moradores, mas pelo menos não era considerado tão "prego"4 por eles. O novo chefe, Pedrinho (Pedro Moura Cardoso), diferentemente de diversos anteriores a ele, especializou-se em oprimir sem justificativa e cruelmente os moradores de Nova Jerusalém.

Conviver com bandidos era algo "naturalmente" enquadrável no cotidiano daquelas pessoas extremamente pobres. Enfrentar um "gigolô", entretanto, correspondia a algo inusual no elenco de precariedades diárias. A eliminação de uma mulher sozinha e indefesa unicamente porque se negara a ceder aos "ins-

\footnotetext{
${ }^{4} \mathrm{Na}$ linguagem típica do mundo criminoso fluminense, é considerado "prego" o bandido que não auxilia a comunidade na qual vive.
} 
tintos animais" de Pedrinho e, fato fundamental porque mais traumático, a eliminação do jovem filho dessa mulher, que além de "inocente" era "débil mental", e o posterior despejo dos dois cadáveres em um canal infecto que delimita um dos lados da favela, onde esses corpos decompuseram-se até serem resgatados posteriormente, significaram para os moradores de Nova Jerusalém a confirmação de algo até então não percebido como normal, porém aceito como parte do cotidiano de incertezas de uma população pobre e desassistida.

Era bastante clara para qualquer morador de Nova Jerusalém a impossibilidade de existirem regras fixas para o comportamento daquelas pessoas que direcionaram suas vidas para a prática de crimes. Justiceiros, ladrões e traficantes são elementos minoritários, porém destacados dentro de uma favela miserável como Nova Jerusalém. É óbvio que os elementos expulsos pelos moradores não eram os primeiros bandidos gerados ou recebidos pela "comunidade". Relatos de moradores deram conta de que, nos poucos anos de existência daquela favela, diversos foram os bandos ou elementos isolados que interferiram na vida dos habitantes. Alguns desses grupos e elementos isolados beneficiaram o conjunto dos moradores, e a sua saída de cena - sempre por meio de assassinato ou expulsão - transformou-se em motivo de pesar e apreensão. Outros grupos, e principalmente elementos isolados, sempre foram vistos como desagregadores e, portanto, como perigosos.

A fala de algumas das moradoras da favela revela essa relação recheada de admiração, medo e respeito:

[...] viver perto de marginais não é uma coisa ruim ou boa. Depende muito de como é o marginal. Sendo cria daqui mesmo ele geralmente respeita todo mundo e ninguém se mete com eles. "Faz" os negócios deles e a gente "vivemos" nossa vida sem se meter nas deles. Uns até "ajuda" quando temos precisão [...] tem uma vez... um caso que eu lembro que foi de uma parenta minha... dois filhos dela "bebia", se "drogava" e "batia" nela. O dono daqui na época era o Beto Baiano que era um sujeito bom. Ela reclamou com ele, que foi até os dois "filho" e avisou que aquilo tinha que parar. Quando um dos filhos bateu nela, o Beto nem foi avisado, foi até a casa e deu uma surra no filho dela. ${ }^{5}$

Olha só, quem mora aqui desse jeito que nós "mora" não dá "pra" não dar com bandido, não. Eles "ê" normal nesse lugar todo daqui, nessas "favela". Eles não são "ruim" ${ }^{5}$ Não creditei os vários depoimentos aqui presentes devido ao risco que isso representa para grande
parte dos entrevistados. 
não. É gente igual à gente mesmo. Ajuda quem precisa aqui e só ataca aqueles que "vacila" no lugar. Eu não reclamo, não, porque é tudo mesmo assim, e quem faz covardia aqui com a gente é muito mais polícia que ladrão. Eu não acho que tem porque fala[r] mal de bandido daqui, não. A gente respeita e tudo porque quem manda “é” eles, mas não “tem” medo deles, não. Às vez[es] não dá pra viver bem com eles quando uns "fica maluco", mas mais certo é não dar problema com a gente, não.

O depoimento seguinte revela, ao contrário da admiração e gratidão, o medo e o desprezo que um morador da favela demonstra ao relembrar episódios antigos envolvendo um justiceiro isolado que atuou no lugar durante algum tempo:

[...] "foi" anos de horror. Era difícil viver com aquele sujeito aqui. A gente não tinha ideia de por que ele era tão ruim, e vivia o tempo todo com medo de ser morto pelo monstro. Às vezes ele banhava cavalo com gasolina, botava fogo e ficava rindo da dor do bicho correndo e derrubando barracos enquanto morria desesperado. Isso era direto, e matava qualquer um sem razão. O negócio dele era mostrar que era ruim, e para isso atirava sem motivo e sem olhar quem passava. Aqui, naquela época, era quase tudo barraco feito de madeira e papelão. Quando começava tiro era um Deus nos acuda. Enfiava minha família embaixo da cama e ficava esperando passar. Não lembro de tempo pior. Tinha que chegar "em" casa antes das nove da noite porque ele escreveu em tabuleta e pendurou aí a ordem de chegar cedo. Depois das nove corria o risco de levar tiro.

Inútil procurar nas falas de moradores de Nova Jerusalém indícios da existência de organizações criminosas assemelhadas àquelas existentes em favelas cariocas. $\mathrm{Na}$ realidade, tanto os depoimentos de habitantes da favela quanto o testemunho de policiais civis e militares conhecedores de ocorrências criminosas que possuíram como cenário aquela favela revelaram que os bandidos dali sempre se caracterizaram pelo uso extremo de violência, seja contra inimigos - o que se constitui em um comportamento regular -, seja contra os componentes da própria "comunidade favelada". Para alguns entrevistados, é muito provável que o pequeno tamanho de Nova Jerusalém e o fato de aqueles bandidos atuarem muito localmente e não correrem riscos dentro do lugar os tenham levado a não refrearem seus atos animalescos:

[...] você tem que ver que isto aqui é muito pequeno quando compara com outras favelas daqui de Caxias mesmo. Bandido daqui nem tem muito "pra” fazer, não, e uns "acaba" querendo sacanear a gente mesmo que mora aqui e que não tem como se defender. O difícil é que você não tem "pra” quem reclamar, mesmo porque se um começa a fazer covardia, os outros não ligam e sua família fica assim sem amparo de 
ninguém, porque não adianta mesmo chamar polícia porque ninguém nem entra aqui. E aí a gente fica sozinho aqui esperando não enfrentar bandido maluco. É um inferno, e já foi pior quando aqui era menor, porque nem sabia quem era dono daqui. Chegava um, matava o que "tava" mandando e sobrava "pra” gente sempre. Vai fazer o quê, né? É tudo tão ruim e não tem mesmo "pra” onde ir. O jeito é ir vivendo aí, com medo da covardia deles.

O assassínio da mulher e de seu filho surgiu para os moradores de Nova Jerusalém como a confirmação de algo até então percebido, porém não admitido: era insuportável continuar a viver dentro daquele clima de horror. Ainda mais que aquela situação não era recente. Pelo menos há três anos os bandidos da favela se aproveitavam da fragilidade de seus habitantes, e mesmo sendo parte integrante da vida dos moradores de áreas pobres da Baixada Fluminense a íntima convivência dos "trabalhadores" com traficantes, ladrões e justiceiros, e não existindo na maior parte dessa região preceitos muito bem definidos para regular tal convivência, para as "comunidades" sempre existem maneiras de antecipar o comportamento dos bandos e a ação individual de seus componentes. A vida pode se transformar em um "inferno" quando um desses bandos ou alguns indivíduos isolados resolvem fugir das tênues regras estabelecidas e se aproveitar da situação de vulnerabilidade que é inerente à vida das pessoas das regiões pobres.

Em uma vida marcada por carências extremas, a impossibilidade de possuir pelo menos "paz" é algo desesperador, e, apesar de todas as crises que circundam a vida dos moradores dos bairros periféricos e das favelas da Baixada, é possível observar que na maior parte do tempo existe a "paz" característica das áreas controladas por um bando ou por um protetor, seja ele um morador, policial, bombeiro, segurança particular, traficante ou um exterminador de bandidos. A exacerbação da inversão das relações existentes entre "trabalhadores" e bandidos na comunidade de Nova Jerusalém preparou lentamente o terreno que permitiu o surgimento da revolta aqui descrita.

Entretanto, não se poderiam considerar como totalmente previsíveis as ações contrárias aos bandidos "pregos". Sem alguns fatos catalisadores, o processo de expulsão dos traficantes da favela e a formação dos grupos armados que passaram a circular pelas ruas da favela a fim de impedir a volta dos componentes do bando de Pedrinho provavelmente não teriam ocorrido. É preciso descobrir o que catalisou a revolta. 
No dia anterior àquele em que os policiais do batalhão da PM receberam a denúncia citada, um jovem chamado Adriano Vianna deu entrada na condição de "conduzido" na 59a Delegacia de Polícia. Fora ele levado até ali porque confessara horas antes ter sido o assassino de dois indivíduos que também eram moradores de Nova Jerusalém.

A história do crime se iniciara na madrugada de sábado para domingo, quando Adriano e alguns outros favelados pararam em uma "barraca" no interior da "comunidade" para beber cerveja, chegando dois homens, que passaram a comentar em voz alta a intenção de eliminar um cunhado e algumas sobrinhas de Adriano. Reconhecendo aqueles homens como bandidos que "infernizavam" a vida dos moradores dali e percebendo que se encontravam bêbados, Adriano e seus acompanhantes aproveitaram-se da oportunidade que surgia inesperadamente e atacaram os "elementos". Tomando a arma que estava em posse de um deles, levaram-nos para um terreno baldio e revezaram-se nos disparos contra os corpos dos dois. Logo em seguida encarregaram-se de arrastar os corpos sem vida até as margens do canal Sarapuí, tendo sido os dois bandidos arremessados sobre a vegetação que cobre as águas fétidas e quase imóveis.

Logo após liderar o duplo homicídio, Adriano, agora sozinho, correu para a casa de Pedrinho, o chefe do bando de traficantes a que pertenciam os dois mortos. Invadindo a casa e sendo atendido por uma menina, Adriano terminou sua aventura noturna tendo uma das pernas atingida por um tiro que partiu do bandido refugiado sob a cama. Avistou-o fugindo pela janela do barraco e logo em seguida escondeu em um matagal a arma com a qual matara e caçara traficantes. Só após se encaminhou para o Hospital Geral de Duque de Caxias, onde confessou aos policiais militares os crimes que cometera durante aquela madrugada. A arma foi recuperada com facilidade, pois estava exatamente onde Adriano disse que deixara. Os corpos não foram imediatamente encontrados, uma vez que o leito do canal Sarapuí se constituía em uma espécie de depósito lamacento de lixo, sendo impossível em alguns pontos descobrir a água que o formava tal o grande volume de galhos, garrafas plásticas e restos de móveis e animais que assoreavam o canal, que possuía águas totalmente enegrecidas devido ao grande volume de esgotos domésticos e industriais despejados nesse "afluente" do rio Sarapuí.

No meio do dia em que Adriano foi preso, a delegacia foi informada da presença de dois corpos presos na lama que margeia o canal do rio Sarapuí exata- 
mente na parte em que este limita a favela de Nova Jerusalém. Eram dois homens de cor negra aparentando o primeiro 40 e o segundo 35 anos. Os dois foram identificados por moradores da favela como sendo os bandidos mortos entre sábado e domingo por Adriano e seus acompanhantes. ${ }^{6}$

Na mesma ocasião em que esses dois corpos masculinos foram encontrados, os policiais e homens do corpo de bombeiros localizaram outros dois cadáveres. Um deles pertencia a uma mulher e o outro, a um jovem. Os populares presentes ao resgate dos cadáveres, além de auxiliarem os soldados bombeiros na localização de todos os corpos, ainda informaram que eles pertenciam a mãe e filho assassinados alguns dias antes pelos componentes da quadrilha de Pedrinho. Os habitantes de Nova Jerusalém disseram que o nome dessa mulher era Iracema, que ela era confeiteira e que o nome de seu filho era Cleomar. Eles foram esfaqueados e atingidos por tiros após a mulher ser estuprada. ${ }^{7}$

A polícia ocupou a favela no dia 9 de julho de 1999. Apesar disso, os moradores não desmontaram seus grupos de patrulha. Armados de paus, foices e facões, continuaram circulando pelas ruas escuras onde os policiais não andavam. $\mathrm{Na}$ verdade, o termo "ocupação" não é totalmente adequado. Para "garantir a segurança dos moradores”, o comando do 15 Batalhão de Polícia Militar escalou 10 militares que se revezariam em duas viaturas durante todo o dia. Uma das viaturas deveria simplesmente circular pela Avenida Presidente Kennedy que delimita a favela, e a outra teria como posto fixo a entrada do lugar, tendo os ocupantes dessa segunda viatura ordens expressas (e desnecessárias) de não circularem pelas ruas de Nova Jerusalém.

De fato, seria estrategicamente inviável para uma viatura policial patrulhar as ruas estreitas, esburacadas e enlameadas da favela. Sendo impossível manobrar naquelas vielas, em uma emergência a ação policial ficaria comprometida, por isso a natureza cosmética da ocupação.

\footnotetext{
${ }^{6}$ Todas as informações anteriores foram retiradas dos seguintes documentos:

Registro de ocorrência n⿳o 0035672/0059/99 da Metropol XI (Título: Flagrante 689/99 - Bem Arrecadado).

Registro de ocorrência no003590/0059/99 da Metropol XI (Título: Encontro de Cadáver - Duplo Homicídio).

Auto de prisão em flagrante n⿳o 689/99 da Metropol XI - 59를 Delegacia de Polícia.

${ }^{7}$ Jornal O Dia, 7 de julho de 1999, p. 10.
} 
A presença policial não fez com que as ameaças de Pedrinho e seu bando cessassem, e moradores eram avisados, quando saíam do local, de que o bando retornaria reforçado e colocaria fogo em todos os barracos, matando aqueles que ainda insistissem em viver por ali.

Em junho de 1999, a recordação dos três últimos anos e principalmente dos três últimos meses fazia com que qualquer habitante da favela entendesse não serem somente bravatas os avisos. Vivo na memória estava o conhecimento dos nove assassinatos de "trabalhadores" ocorridos na favela durante os três últimos meses. Dois dos assassinados estavam sendo retirados do "valão" naquele momento. Os outros sete nem sequer seriam enterrados, uma vez que foram também lançados ao canal ou rio, mas devido ao longo tempo que permaneceram ali provavelmente já não poderiam ser resgatados.

As lembranças do terror, o medo desesperador e a certeza de que os policiais, "mesmo se quisessem", nada poderiam fazer para protegê-los convenceram aqueles moradores - sem que existisse a necessidade de nenhuma reunião formal - de que o único meio de defesa era representado pela reação violenta contra o que profissionais do jornal carioca O Dia chamaram de "ditadura do pó".

A reação popular não era encabeçada por qualquer organização existente dentro ou fora da favela. A associação de moradores não possuía formas de ação contra os bandidos, algo comprovado pelo fato de um de seus líderes também estar ali no "valão", assassinado pelos bandidos meses antes daquele momento e jamais resgatado. ${ }^{9}$

A inexistência de lideranças catalisadoras não tornava menos efetivas as decisões populares. Ainda mais que tais decisões inspiravam-se em um exemplo de reação que ocorrera naquele mesmo local no dia anterior. A expressão daquele exemplo constituía algo tão forte que se tornava difícil não segui-lo mesmo que isso significasse colocar em risco a própria vida:

\footnotetext{
${ }^{8}$ Jornal O Dia, 7 julho de 1999, p. 8.

${ }^{9}$ A história do líder da associação de moradores assassinado é confusa e se repete sob formas diferenciadas em muitos dos relatos que ouvi. As narrativas mais comuns apresentam um líder comunitário - que era também pastor de uma igreja neopentecostal - que ao subir no telhado de sua casa para verificar a antena da televisão foi mal interpretado pelos bandidos que já não gostavam dele e que pensaram tratar-se de espionagem. Foi atingido por tiros e seu corpo quebrou as telhas de um barraco ao cair. Arrastado pelo bando, teve sua cabeça arrancada e transformada em bola de um jogo macabro de futebol.
} 
Não é que a gente não tivesse o que perder. É claro que todo mundo lá tinha o que perder. Por mais miserável que a pessoa é tem pelo menos parente, família [...] se arriscar é difícil quando você é pai, filho, esposo. Ninguém com consciência deixa mulher, mãe, filho em casa e sai pela rua caçando malandro que não tem o que perder. Só maluco ia fazer isso sem ter motivo, e mesmo tendo esse motivo eu pensei muito antes de participar daquilo. Só me envolvi quando percebi que se não fizesse isso ia seguir o mesmo caminho dos outros e sair da favela. Só que sair era ruim também. Pior que esse lugar é, eu gastei aqui e deixar família sem ter onde morar é difícil. Eu não tinha "pra" onde correr e passei a participar do negócio porque não dava de encontrar outro jeito de resolver. A única esperança é que os bandidos morressem logo, porque bandido morre cedo. Mas naquela hora não tinha o que pensar. $\mathrm{O}$ jeito era vigiar rua e torcer para não acontecer nada [...], "pra” eles não "voltar", porque eu não sei como ia ser enfrentar eles com revólver e nós com pau e pedra. Ia ser um massacre dos dois lados, e ainda bem que o pior não aconteceu.

Já não era possível a impassibilidade diante do que ocorria, e a partir da madrugada do dia quatro para o dia cinco de julho a explosão tornou-se impossível de ser contida.

Conhecer as circunstâncias possibilitadoras do surgimento de Nova Jerusalém é fundamental para a compreensão dos fatos aqui descritos.

2

A história da ocupação de Nova Jerusalém dificilmente poderia ser contada tomando como ponto de partida a maneira como ocorreu a colonização proletária da Baixada Fluminense. Em primeiro lugar, essa favela surgiu muito recentemente, sendo a própria existência de favelas algo relativamente novo na Baixada. Somente a partir de meados da década de 1980 tal forma de agrupamento popular começou a surgir nessa periferia de forma mais explícita. As exceções a tal regra são algumas favelas razoavelmente antigas e localizadas em alguns municípios vizinhos ao Rio de Janeiro, como Duque de Caxias, São João de Meriti e Belford Roxo. Nova Jerusalém não pertence a esse grupo mais antigo.

As razões para as favelas não serem típicas da Baixada prendem-se à ocupação da região por meio do loteamento de terras agrícolas fracassadas, portanto a partir da compra do lote, e não da apropriação de áreas geralmente públicas, que se constitui na maneira principal de formação das favelas cariocas.

É algo difícil reconstituir passo a passo e desde o seu início o processo de formação da favela de Nova Jerusalém. As informações são fragmentadas, não 
sendo possível localizar moradores muito antigos dali, onde as pessoas sequer sabem por que esse nome foi escolhido para o conjunto de miseráveis barracos de madeira, restos de metais e alvenaria que ocupam um corredor localizado entre o rio Sarapuí e o canal que corre paralelamente ao rio.

Sendo mais preciso, as favelas contidas no bairro de Gramacho localizam-se sob as torres de alta tensão da companhia elétrica que abastece a maior parte da Região Metropolitana do Rio de Janeiro (Light), próxima dos tubos condutores de combustíveis pertencentes à Refinaria Duque de Caxias da Petrobras e praticamente dentro do rio Sarapuí, que, nesse trecho final de seu curso, apresenta-se totalmente contaminado pelos esgotos residenciais e industriais de parte da Baixada Fluminense e da Zona Oeste do município do Rio de Janeiro. A favela margeia a principal avenida do município de Duque de Caxias (avendida Presidente Kennedy), localiza-se a poucos passos dos trilhos de um dos ramais da Estrada de Ferro Leopoldina e está praticamente dentro do centro comercial do bairro. Não é essa uma favela solitária. Um pequeno "complexo" de "comunidades" há ali margeando o rio Sarapuí, a avenida Presidente Kennedy e os trilhos de trens urbanos, sendo componentes desse complexo o Dique II, a Paraopeba, a Vila Fraternidade e a Teixeira Mendes.

O rio e o canal (tanto um quanto outro chamados pelos moradores de "valão") estão de tal maneira impregnados de lixo que mal correm e principalmente em dias de calor transformam o ar em algo um tanto desagradável para narizes não acostumados ao mau cheiro. Aliás, a insalubridade do local é provavelmente uma das causas para não existirem moradores de longa data ali.

Apesar desse aspecto de campo de refugiados, é impreciso dizer que Nova Jerusalém é um lugar provisório de moradia. $\mathrm{O}$ fato é que inexistem ali pessoas que desejem manter-se habitando por muito tempo a favela; em outras palavras, não parece haver sinais de apego àquele local de moradia, o que não chega a ser uma surpresa, principalmente após visitarmos os barracos miseráveis ou mesmo circularmos pelas vielas.

O interior dos barracos, quase sempre edificados com sobras de materiais de construção, possui no máximo três pequenas repartições, sendo mais comuns aqueles com dois cômodos, estando a cozinha, o quarto e a sala em um mesmo lugar. Sobre um chão de terra batida, móveis doados ou retirados do aterro sani- 
tário de Jardim Gramacho servem aos moradores, que cozinham seus alimentos, em alguns casos, em recipientes de lata transformados em panelas.

Quanto às vielas, são de tal forma estreitas que impossibilitam duas pessoas caminharem uma ao lado da outra. Apesar disso, metais retorcidos, latinhas de alumínio e materiais restantes da construção dos barracos se acumulam nas portas, impedindo a passagem em alguns pontos até mesmo de uma pessoa sozinha. Para completar o cenário, em todos os pontos desse lugar caótico pequenas valas recebem a água da cozinha e os detritos dos banheiros das habitações, o que transforma os espaços destinados à passagem das pessoas em uma pista de obstáculos vencida unicamente por meio de pequenos e escorregadios saltos.

Informações acerca do início do processo de ocupação das áreas próximas ao rio Sarapuí variam conforme a fonte. A Prefeitura Municipal de Duque de Caxias, o 15으 Batalhão de Polícia Militar, a 59aㅡ Delegacia de Políciaa e os moradores dos bairros circundantes discordaram bastante ao fornecerem dados. $\mathrm{O}$ primeiro órgão apontou o início da década de 1990 como o momento inicial de ocupação, já o segundo considera que em meados da década de 1980 já existiam barracos construídos ali. Quanto aos moradores mais antigos do bairro de Gramacho, dizem que pelo menos há 30 anos existem barracos à beira dos cursos de água que atravessam o bairro a caminho da baía de Guanabara. Dizem eles, também, que tais barracos eram mínimos, “10, 15, 20 barraquinhos”. De um momento para outro, as margens do rio foram sendo mais ocupadas, até se tornarem favelas:

Não lembro bem, não, mas acho que isto começou a ter barraco no primeiro governo do Brizola. De lá pra cá foi só aumentando, até ficar do jeito que é. Mas começou devagarinho. Um barraquinho aqui, outro ali, e depois foi fechando assim e enchendo mais ainda, e parece que foi aumentando quanto mais o Gramacho progredia. Aumentou mais porque aqui era final dos trens [a estação de Gramacho até pouco tempo era a última no ramal de trens elétricos. A partir dali, o passageiro migrava para trens puxados por locomotivas a motores diesel], que daqui "pra frente" tem menos e se o cara quiser ir para a cidade fácil é melhor parar aqui mesmo, porque lá pra dentro tem menos recurso e é mais difícil "pra" ir trabalhar lá "pra" baixo ["dentro" e "baixo", para vários entrevistados, designam, respectivamente, lugares mais afastados do município do Rio de Janeiro e o centro da capital fluminense].

Segundo dados da 59a Delegacia de Polícia Civil, as primeiras ocorrências policiais surgiram naquela área no ano 1988, o que sugere que as margens do rio 
Sarapuí abrigaram favelas mais complexas em finais dos anos 1980. Essa última informação, completada pelos relatos de moradores de Gramacho, faz com que consideremos o início dos anos 1980 como aquele em que pessoas iniciaram construções de barracos em torno dos rios e estradas da região.

Quanto aos motivos que conduziram habitantes para os núcleos de habitações miseráveis e a origem desses homens e mulheres, há informações menos imprecisas que a datação de surgimento da favela. Somente com base nas entrevistas era possível supor que em boa parte os habitantes dali derivavam de bairros periféricos da própria Baixada. Geralmente, emergências conduziram as pessoas até ali. A fala seguinte sintetiza o caráter dramático da chegada a Nova Jerusalém:

[...] tem uns dois anos que mudei "pra" cá, e o motivo foi a morte de um filho. A gente morava no Lote XV [bairro localizado no limite de Duque de Caxias com o município de Belford Roxo], em uma casa construída em um terreno que foi doado "pra" nós [...] o mais novo se envolveu com o que não presta e um dia invadiram e quebraram tudo na casa. Procuravam ele, que quase nem ia mais "em" casa [...] ameaçaram e deram um dia "pra" gente mudar. Na mesma noite acharam e mataram ele, e a gente nem pôde fazer o enterro direito. Continuaram ameaçando e no dia seguinte a gente veio parar aqui.

Fizemos uma cabana com plástico de obra mesmo e ficamos dentro da cabana mais de 15 dias. Nesse tempo, juntamos resto de obra lá no lixão e fizemos esse barraquinho em que a gente até hoje mora.

Não se constitui exatamente em uma exceção a situação anterior. Vítimas de atos violentos, fugitivos de locais onde se tornou impossível viver "em paz", miseráveis absolutos, catadores de lixo que diariamente "trabalham" no lixão de Jardim Gramacho, serventes de pedreiro, empregados domésticos compõem o conjunto de habitantes dos barracos e casebres que fazem parte da favela. Muito raramente encontramos trabalhadores formais dentro dessa espécie amorfa de comunidade.

Guiando-se unicamente pelos depoimentos, é fácil pensar a favela caxiense como algo assemelhado a um depósito de rebarbas produzidas no processo desorganizado de urbanização da região da Baixada Fluminense, e o fato de localizar-se em Duque de Caxias reforça mais ainda tal ideia, na medida em que aquele município foi o que experimentou de maneira mais explosiva a ocupação popular. Na realidade, é possível encontrar ali em Nova Jerusalém práticas semelhantes 
àquelas presentes ordinariamente nos bairros periféricos da Baixada. Entretanto, ocorre nessa favela o que considero como agudização dos problemas típicos dali, sendo tal intensificação de problemas agravada pela completa ausência de instituições ou ações que representem o Estado. Mesmo a polícia, como já vimos, visita Nova Jerusalém somente em emergência extrema. Circular pela favela, na visão de um oficial da $\mathrm{PM}$, seria algo infrutífero, por uma série de motivos:

Por que eu deslocaria patrulhas para lá? O máximo que existe naquele lugar é bandido que utiliza os barracos como esconderijo. Não tem ninguém com dinheiro por lá. Você poderia pensar que nós deveríamos ir até lá para prender bandidos escondidos. Mas isso é perda de tempo. Nosso efetivo não é grande, e o que não chama atenção geralmente não é verificado. Parece insensível isso que eu falo, mas é a realidade. Precisamos oferecer resultados, e nessas pequenas favelas e bairros pobres só pode existir deslocamento em caso de alarme. Do contrário, consideramos as nossas ações perda de tempo.

Mesmo o assistencialismo político, comum em qualquer região pobre, ali não é praticado muito provavelmente por significar uma ação inútil. Espera-se que o beneficiado pelas doações dos agentes assistencialistas comprometa-se e retribua mediante o voto. Ocorre, entretanto, que carências tão extremas são acompanhadas ali de descompromisso eleitoral, sendo poucos os moradores de Nova Jerusalém preocupados em participar de eleições, mesmo quando possuem títulos de eleitor. ${ }^{10}$

[...] ninguém faz nada sem interesse, e "pra" que "vim" aqui se o povo daqui não vota? Às vezes aparecem uns políticos aqui e dão sopa "pro" povo daqui, mas parece que "desiste" porque não dá resultado "vim" aqui e gastar dinheiro com quem não vota e não faz eles ficarem mais rico do que já "é" [...] a gente tem de se conformar com o que a gente é, e não é por político que esse povo vai ter alguma coisa. Todo mundo daqui tem que vê que está abandonado e ninguém vai se preocupar com esse povo que não pode ajudar político a enriquecer.

De certa forma, a última fala conduz-nos a pensar que a favela transformou-se em um caso extremo de esquecimento estatal dentro de outro caso de esquecimento, que é a periferia das várias cidades que circundam o Rio de Janeiro. A própria ocupação dali deu-se de maneira crítica: entre dois cursos de água, a favela goza do infeliz status de ser marginal duas vezes.

\footnotetext{
${ }^{10}$ Adiante apresento dados da porcentagem de votantes em Nova Jerusalém.
} 
Acompanhar a trajetória errática do jovem catador de lixo Adriano Vianna parece-me essencial na compreensão do contexto originador da revolta aqui descrita.

Penso não ser possível assemelhar Adriano Vianna ao conjunto dos bandidos da favela. Mesmo a polícia reconheceu a diferença entre suas ações e os assassinatos levados adiante pelos traficantes. Seus atos não foram planejados e afiguraram-se em todos os momentos como gratuitos. O fato de não ter fugido, de procurar um hospital público por causa de um ferimento não muito grave, contar aos policiais, com riquezas de detalhes e despretensiosamente, cada um dos passos de sua ação justiceira revelou ingenuidade e conformismo com as consequências que adviriam de seu comportamento. Poder-se-ia pensar que para o catador de lixo sua conduta não era criminosa. Esse pensamento não é corroborado, entretanto, pelas impressões dos dois policiais que o conduziram até a delegacia:

Em nenhum momento ele demonstrava arrependimento, e de início eu pensei que ele não tinha consciência do que fez [...] só que ele sabia exatamente que consequência teria aquilo e tinha medo de ficar com bandidos. Pedia para a gente colocar ele separado dos outros por que ele ia ser morto por bandidos se ficasse em cela comum. "Me pareceu" muito assustado e admirado por ter feito aquilo. Não dizia que fez sem pensar, mas achava que não tinha outra saída. Se não fizesse, seus parentes iam morrer. Via em nós dois não policiais, e sim amigos dele. Parece que achava que a gente podia proteger ele dos outros bandidos da favela.

[...] ele não aparentava arrependimento, mas parecia estar morrendo de medo. Podia muito bem dizer que foi vítima de bala perdida, que naquela época era moda todo malandro dizer que era vítima disso. $\mathrm{O}$ mais engraçado é que ninguém forçou ele contar nada. Chegou lá nem tão ferido assim e foi logo dando o serviço, como se matar dois "era" uma coisa normal. Explicou direitinho onde os corpos e a arma estavam e ainda nos disse onde estava o corpo do rapaz excepcional e da mãe dele ["dele", "rapaz excepcional"], não tinha jeito de bandido e parece que não tinha nenhuma experiência. Voltou na favela com a gente no dia seguinte e não se negou a ajudar ao máximo. Eu pelo menos achava que ele nem tinha que ir preso. Mas cumpria meu papel tranquilo porque sabia que ele não fugiria. Na minha opinião, ele era verdadeiro em tudo que contava e era mais vítima que os mortos.

O que Adriano não podia imaginar era o alcance de seus atos daquela madrugada. Era impossível para ele imaginar-se um exemplo e o incentivador de uma estranha, porém competente, revolta popular. 
Alguns detetives da 59를 Delegacia de Polícia consideraram que o caso Adriano somente tomou um rumo favorável ao rapaz porque "a favela se revoltou". Desde o início eles perceberam que aquelas mortes não eram "exatamente assassinatos", porém, se os favelados não tivessem se revoltado, Adriano não teria chamado a atenção da imprensa, e as chances de sua sobrevivência à prisão seriam muito pequenas. Segundo os policiais, justiceiros são muito mal vistos dentro das celas de delegacias, e mesmo ficando isolados acabam sendo perseguidos e mortos quando soltos. Aliás, a situação de Adriano já era bastante complicada independentemente de sua categoria de justiceiro.

No mundo do crime, a solidão não é bem vista, e Adriano, embora tenha recebido ajuda para matar os bandidos, era o único preso e não era um dos dentes de nenhuma engrenagem criminosa. Antes, era um elemento isolado e por isso mesmo um marginal entre marginais. A falta de companhia o transformava em uma vítima-algoz completamente indefesa. Contra ele, um ódio muito parecido com o ódio que existe contra policiais passaria a existir caso fosse colocado junto com os demais presos.

É claro que tudo que ele praticou durante aquela madrugada não poderia ser obra de qualquer membro da comunidade; entretanto, as lembranças e sentimentos dele enquanto cometia os atos da madrugada eram pertencentes não somente a Adriano Vianna, porém a todos aqueles que dividiam a favela de Nova Jerusalém.

Qualquer um de nós podia ter feito o mesmo. Ele não era diferente de ninguém, teve a chance, era novo e tinha disposição, e aí se livrou dos bandidos. "Tá" certo pensar que ele começou a coisa "pra” gente, mas não dá "pra” pensar que ele é herói. Ele teve chance de matar e matou. Só acho que ele foi burro, porque se ficasse na dele ninguém ia nem saber de nada. Só que foi falar e acabou preso e depois sumiu.

Acho que ele só fez o que todo mundo daqui queria fazer. Eu lembro direitinho, porque tanto o Maninho quanto o Seu Boneco abusaram da minha filha, e "ameaçou" me matar e todo mundo da casa também. Ele não aguentou mais e não tinha muito "pra" perder mesmo, e aí barbarizou os monstros. Eu fui lá no valão "pra" ver os corpos saindo depois, e cuspi nos desgraçados mesmo. Fez certo mesmo. Eu queria mesmo era [ar] rancar as bolas daqueles desgraçados.

Há outro aspecto presente nos atos de Adriano. Exatamente por respeitar a memória compartilhada pelos favelados, esses delitos foram entendidos pelos 
moradores como pertencentes não a Adriano e, sim, a todos os oprimidos pelos bandidos:

A mão foi do Adriano, mas de verdade mesmo as mortes foram da gente daqui. Todo mundo sempre teve vontade de matar aqueles desgraçados, e quando a chance chegou ele fez o que a gente queria, mesmo sem pensar na gente.

Bandido tem mesmo que morrer assim quando é prego igual àqueles. Eu orei muito "pra" eles morrerem e eles não morriam. Olha que eles viviam brigando um com os outros, e nada de morrer. Vivia[m] dando tiro "pra" o outro lado do rio e botando a vida das crianças no risco, e nada de morrer. Pena que ele se entregou porque se apavorou. Se não fala nada e a gente expulsava os resto[s] igual a gente "fizemo" e ninguém nem ia saber. Tanta coisa que tem aqui e ninguém sabe de nada não. Foi mole dele ir "pra" hospital.

Daquele momento em diante, parece ter se desenvolvido rapidamente entre os membros da "comunidade" a percepção da invisibilidade pública que suas vidas e valores representavam, o que parece ter acelerado o surgimento da vontade de "fazer justiça com as própria mãos". Entre as mortes e a revolta popular não houve nenhuma tentativa de acionar o poder público além do "mole" de Adriano. Talvez fosse claro demais para o conjunto dos favelados que a presença policial ali ocorreria unicamente como algo extraordinário e como parte das averiguações realizadas a fim de se montar o processo contra Adriano. Certo era para todos que as viaturas policiais que se postaram na entrada de Nova Jerusalém na manhã da segunda-feira não estavam ali a fim de garantir a segurança dos habitantes da favela, que recebiam ameaças ainda mais ferozes por parte dos bandidos remanescentes, para os quais era fundamental não permitir reações como a de Adriano. Afastados, mas rondando a favela apesar da presença da PM, os bandidos remanescentes desejavam revanche e avisavam que voltariam após a saída dos policiais e tratariam de queimar todos os barracos da favela:

Depois que tiraram eles do valão, a gente viu que não ia dar não "pra” ficar aqui. Uns começaram a sair, mas não dava "pra" todos irem, e aí o jeito foi botar eles "pra" correr com o que a gente tinha mesmo. Isso era um inferno mesmo, e os que estavam aqui ainda "tava" começando a querer massacrar a gente, aí o jeito foi aquele. Eu lembro que uns moleques da favela pegaram arma e bateram na cabeça de uma velha ali no fim da rua e ameaçaram umas meninas que falavam no Adriano. Aí, quando não tinha mais polícia, começou tiro e tudo e botaram gasolina em um barraco que tinha ali embaixo perto do rio e que "tava" vazio na hora e queimaram tudo da mulher que morava lá, e começou a barbaridade mais ainda e aí acabou explodindo tudo. Não 
dava mais, e aí a gente se virou do jeito que você sabe [...] não foi assim porque a gente queria expulsar eles, não. Mas não dava mais mesmo, e aí explodiu tudo mesmo.

Tornou-se impossível para o conjunto dos habitantes de Nova Jerusalém a precária convivência com os bandidos dali e passou a ser fatal um confronto direto, uma vez que "não passava pela cabeça de ninguém chamar a polícia”. Encurralados pelo bando de Pedrinho, a única opção existente para os que não fugiram da favela foi o abraço a uma maneira desesperada de união: a constituição dos grupos armados que ficaram responsáveis pela expulsão dos últimos bandidos e pela inviabilização da volta de todo o bando de Pedrinho para o espaço da favela.

Quando mergulhamos na direção do centro desse caso e conhecemos seu contexto, percebemos que ele funcionou como um momentâneo divisor de realidades. No período imediatamente anterior às mortes dos dois bandidos, a situação naquela favela excedia em muito aquilo que cada morador entendia como o tanto suportável de violência:

O grupo do Pedrinho [Pedro Moura Cardoso, líder dos bandidos mortos por Adriano ou expulsos de Nova Jerusalém pelos moradores] estava lá há muito tempo, só que não era tão horrível como naquela época [...] eles não era[m] vagabundo igual à maior parte [...] eles barbarizava[m] o tempo todo e ficaram malucos de a pouco tempo: estuprava[m] qualquer uma, matava[m] com pedrada, paulada, facada e jogava[m] no rio. Ninguém escapa. Trabalhador morre. Pastor morre. Maluco morre. Mulher é morta. [...] sem chance de ficar lá com aquilo rolando daquele jeito.

A gente... todo mundo... convive bem com a bandidagem de lá. Só que aquilo não era normal. Barraco incendiado, criança estuprada, velha jogada no rio, trabalhador, pastor morto por bobeira. Passou do limite a barbaridade deles. Ninguém quer se misturar com bandido. Quer só viver onde dá "pra” gente. Do jeito que era não dava pra aguentar aquilo.

Após o caso, uma espécie amarga de esperança passa a ser observada e é rememorada pelas falas dos entrevistados:

Ninguém daqui queria fazer daqui o céu [...] era só uma reação às maldade[s] deles. [...] ninguém tinha chance se não fizesse aquilo lá. Todo mundo via chance de ser morto ou tomar porrada deles. Difícil demais antes deles irem embora viver [...] agora, não é que tenha mudado tudo, mas dá "pra" sair mais tranquilo pelo menos. Dá menos medo agora.

Depois de tudo aquilo, a gente passou a ter mais paz e viu que dava para reagir e viver de um jeito menos [indecisão], agora tenho medo, mas é menos que no tempo 
do Pedrinho. Lá era um inferno, e o único jeito era sair. Só que nós não “tinha” para onde ir. Se saísse ia para a rua virar mendigo.

Nova Jerusalém não deixou de ser o que era devido à ação de Adriano e de seus outros moradores. Esse episódio equivaleu no máximo a um ínfimo hiato em sua rotina violenta. Logo após o caso da expulsão dos traficantes, tudo voltou a girar em seu eixo "natural": os moradores lentamente foram afrouxando a guarda, se desarmando, a favela percebeu que era muito mais seguro aceitar o surgimento de um "dono" não muito "selvagem". "Antes disso, entretanto, Adriano Vianna foi libertado e desapareceu de cena, provavelmente transformado em office boy por meio da ação de uma organização não governamental de defesa dos direitos humanos localizada no município vizinho de São João de Meriti.

Variações do caso Adriano são bastante comuns em jornais populares de diversas regiões brasileiras, e é possível dizer que casos semelhantes a esse expressam a escalada assustadora de violência que vive grande parte das regiões metropolitanas latino-americanas nas últimas décadas.

A singularidade da ação de Adriano e de seus vizinhos de infortúnio deve-se não exatamente ao fato de a história ter se passado na Baixada Fluminense, nem sequer porque ela revela a degradação do meio físico e humano do segundo, muito desigual e mais evidente conjunto urbano nacional. Independentemente de estarmos interessados em entender suas causas ou seus efeitos, a ação de Adriano e de seus vizinhos outorgou aos personagens deste relato o status de cicerones involuntários de uma viagem pelas características políticas, econômicas e sociais dessa região.

Favelas na Baixada Fluminense são cada vez menos excepcionais. A cada dia essas novidades ganham mais força e revelam um aspecto subterrâneo da vida baixadense. Na medida em que os municípios da região se desenvolvem economicamente e abandonam o adjetivo de "dormitórios", assemelhando-se cada vez mais ao município do Rio de Janeiro, uma nova dinâmica orienta a ocupação do solo urbano da Baixada, e as favelas surgem nesse cenário como uma incômoda vizinha dos bairros populares resultantes da aglutinação dos diversos loteamen-

\footnotetext{
${ }^{11}$ Expressões utilizadas pelo presidente da associação de moradores de Gramacho a fim de demonstrar que somente é possível alguma estabilidade nas favelas de Gramacho quando elas possuem chefes de traficantes fortes e protetores dos favelados (Daniel Damasceno, entrevista concedida em 20 julho de 2004).
} 
tos originários, revelando uma relação conflituosa entre habitantes de antigos e novos locais de moradia dentro das áreas proletárias dessa periferia.

Quando me propus construir um relato dos atos do jovem catador de lixo Adriano Vianna, conscientizei-me de que era imperativo visitar a favela de Nova Jerusalém, principalmente porque precisava construir os documentos que embasariam minhas análises. Os poucos lances da vida daquela favela revelados nos parágrafos anteriores são suficientes para sugerir quais dificuldades podem ser encontradas para estranhos que desejem entrar e permanecer em segurança naquela "comunidade". ${ }^{12}$ Como o bom-senso me dizia que a abordagem direta era o melhor e mais perigoso dos métodos de investigação, tentei atingir a favela por dois caminhos diversos. Pareceu-me óbvio procurar o próprio Adriano ou conhecidos e vizinhos seus no local em que ele "trabalhava" na época dos crimes. O "lixão" (aterro sanitário) de Jardim Gramacho parecia-me o local ideal para a busca de informações. Ali, alguns conhecidos do catador de lixo foram encontrados por mim. Porém, logo percebi que eles me informavam o pouco do que havia para se dizer sobre o jovem catador de lixo, e nada sobre Nova Jerusalém. As informações sobre Adriano eram bem-vindas, mas eram também insuficientes para meus propósitos. O segundo caminho imaginado por mim, e que me pareceu inicialmente ser o menos frutífero, acabou revelando-se superior. Resolvi visitar as cercanias da favela e, a partir da suposição de que os primeiros moradores dali deveriam pertencer a algum grupo evangélico (o nome da favela sugeriu-me tal), entrei em contato com lideranças e componentes das diversas igrejas neopentecostais que cercam a favela ou que estão no centro do bairro de Gramacho. Descobri rapidamente que grande parte dos moradores de favelas daquele bairro eram membros daquelas igrejas, o que significou o encontro de testemunhas que habitavam o interior da favela. Ganhava, assim, ao mesmo tempo material bruto para ser lapidado e parceiros para um trabalho que eu não ousaria realizar diretamente: levantar os dados social-político-econômicos dos habitantes de Nova Jerusalém. Além disso, vi a possibilidade, por meio de meus primeiros contatos com os habitantes de Gramacho, de confrontar as falas dos moradores do bairro com o discurso dos moradores favelados. Aliás, mesmo antes de qualquer entrevista formal era possível perceber alguma animosidade entre esses moradores.

\footnotetext{
${ }^{12}$ As minhas visitas à favela de Nova Jerusalém ocorreram no início da investigação e cessaram por completo após a verificação de que os riscos eram maiores do que aqueles que eu aceitava correr.
} 
Os adjetivos para qualificar Nova Jerusalém (ou Jerusalém, como grande parte dos habitantes de Gramacho chama indistintamente as favelas que margeiam o rio Sarapuí) ou seus moradores revelam o quanto é incômodo conviver com a "perigosa" novidade representada pelas favelas.

O pastor Caio e o senhor Daniel foram os primeiros moradores do bairro de Gramacho entrevistados por mim de maneira menos informal. Os dois, envolvidos de maneiras diversas com mobilizações populares nesse bairro, contaram-me histórias em certos aspectos muito semelhantes sobre a favela e seus habitantes. Resumo duas dessas histórias como forma de demonstrar a estranheza do bairro em relação à favela.

De acordo com o pastor Caio, uma das mulheres moradoras de "Jerusalém" passou a frequentar sua igreja. Essa mulher, que possuía três filhos, sendo “[...] cada um de um pai diferente", não possuía casa naquela favela e residia em uma "tenda" montada com "resto de obra", e assim que chegou à igreja começou a ser ajudada, recebendo cestas básicas. Não satisfeita com a assistência "dos irmãos", constantemente procurava o pastor, porque queria comprar um barraco na favela. Encontrou um barraco à venda ali e disse que ele custava mil reais. Como não possuía o valor e todos ficaram "apiedados" com a situação daquela mulher e de seus filhos, uma "vaquinha" foi feita entre os fiéis e o barraco foi comprado. Passado algum tempo, a mulher desapareceu dos cultos e começou a ser vista de "bermuda"13 nas ruas de Gramacho. O pastor soube que ela arranjara um homem da favela e que já estava grávida. Passado mais algum tempo, ela voltou à igreja, já com um novo filho e sem o barraco, que fora vendido pelo pai desse seu quarto filho. Dessa vez, o próprio pastor deu ordem ao "departamento de assistência social da igreja" para que "[...] nem um grão de arroz saia de lá para alimentar aquela mulher e seus filhos".

A história do senhor Daniel diz respeito também à tentativa de ajudar uma moradora da "comunidade favelada". O relato desse incidente veio à memória do presidente da associação de moradores quando se referiu à dificuldade que era ajudar alguém de Nova Jerusalém. Seu "tormento" começou quando foi procurado por uma moradora da favela, que chorava e tremia muito porque "tinha sido expulsa mais os seus filhos da favela com a roupa do corpo", enquanto o seu

${ }^{13}$ A igreja evangélica da qual o senhor Caio é pastor proíbe o uso de "trajes masculinos" por parte das mulheres. 
barraco era incendiado. A expulsão e a queima dos poucos bens da família se deram porque as filhas dessa mulher estavam crescendo e os bandidos desejavam "usá-las como mulheres", porém a mãe se opôs àquela situação de uma forma muito vigorosa, o que resultou em um ataque de raiva de alguns bandidos, que disseram que ela e seus filhos deveriam sair dali o mais rapidamente possível para não morrerem. O senhor Daniel alojou a família provisoriamente em uma igreja e conseguiu em um bairro "de dentro de Caxias" um sítio onde a família poderia morar e trabalhar. Julgava ele que poucas pessoas dentro e fora da favela souberam de sua interferência no caso. Acontece que pouco tempo após o ocorrido ele foi parado por uma mulher enquanto fazia compras em uma mercearia. A mulher, que ele não conhecia, mas soube logo que morava na favela, acusou-o de ajudar inimigos de traficantes e disse que o "dono" da favela queria falar com ele. A partir daí sua vida tornou-se "um tormento". Desconfiava que tudo aquilo não passasse de boato, mas temia por sua família, principalmente porque não compreendia os motivos dos bandidos. Após algum tempo de muita apreensão, tudo se acalmou, porque os traficantes da favela começaram a brigar com maior constância e ele, provavelmente, não era mais importante que os motivos daquelas brigas. A morte do traficante que supostamente o ameaçara afastou de forma definitiva o perigo. As duas experiências demonstraram a esses moradores antigos de Gramacho que é muito perigoso e pouco compensador envolver-se com os habitantes da favela.

Periférica em relação aos bairros populares, as recentes favelas da Baixada Fluminense são flagrantemente diversas dos bairros populares ali presentes ou das favelas tradicionais, sendo detentoras de uma estabilidade social muito menor que esses outros locais de habitação proletária.

A comprovação desse fato efetiva-se quando comparamos dados que se referem especificamente à favela de Nova Jerusalém com os dados gerais da Baixada Fluminense, do município de Duque de Caxias, do município do Rio de Janeiro e do próprio bairro em que se localiza a favela: ${ }^{14}$

\footnotetext{
${ }^{14}$ Os números referentes à favela e ao bairro são resultado da resposta de um questionário denominado Levantamento de dados sociopolítico-econômicos dos bairros de Gramacho e Capivari. Os números referentes a Duque de Caxias, ao município do Rio de Janeiro e à Baixada Fluminense foram retirados dos Censos 1991 e 2000 do IBGE.
} 


\begin{tabular}{|c|c|c|c|c|c|}
\hline & $\begin{array}{c}\text { Nova Jerusalém } \\
\text { (favela) }\end{array}$ & $\begin{array}{l}\text { Gramacho } \\
\text { (bairro) }\end{array}$ & $\begin{array}{c}\text { Duque } \\
\text { de Caxias }\end{array}$ & $\begin{array}{l}\text { Baixada } \\
\text { Fluminense }\end{array}$ & $\begin{array}{l}\text { Rio de } \\
\text { Janeiro } \\
\text { (capital) }\end{array}$ \\
\hline $\begin{array}{l}\text { Ano de coleta } \\
\text { dos dados }\end{array}$ & 2004 & 2004 & 2000 & 2000 & 2000 \\
\hline $\begin{array}{l}\text { Média de mora- } \\
\text { dores migrantes }\end{array}$ & $25 \%$ & $78 \%$ & $70 \%$ & $81 \%$ & - \\
\hline $\begin{array}{l}\text { Média de mora- } \\
\text { dores originários } \\
\text { da Baixada }\end{array}$ & $70 \%$ & $18 \%$ & - & - & - \\
\hline $\begin{array}{l}\text { Tempo médio } \\
\text { de permanência } \\
\text { no local }\end{array}$ & 3 anos & 23 anos & - & - & - \\
\hline $\begin{array}{l}\text { Motivo da } \\
\text { chegada ao local }\end{array}$ & $\begin{array}{c}\text { Fuga de violência } \\
\text { direta em outras } \\
\text { áreas da região } \\
\text { metropolitana } \\
(70 \%) . \\
\text { Falta de condi- } \\
\text { ções de pagar } \\
\text { aluguel em } \\
\text { outras áreas da } \\
\text { região metropo- } \\
\text { litana }(30 \%)\end{array}$ & $\begin{array}{l}\text { Procura de } \\
\text { um local } \\
\text { melhor para } \\
\text { trabalhar } \\
\text { (80\% das } \\
\text { respostas) }\end{array}$ & - & - & - \\
\hline $\begin{array}{l}\text { Área da habita- } \\
\text { ção (média) }\end{array}$ & $15 \mathrm{~m}^{2}$ & $63 \mathrm{~m}^{2}$ & - & - & - \\
\hline $\begin{array}{l}\text { Média de } \\
\text { moradores da } \\
\text { habitação }\end{array}$ & 6 & 5 & - & - & - \\
\hline Média salarial & $\begin{array}{l}\text { Até um salário } \\
\text { mínimo }\end{array}$ & $\begin{array}{l}\text { Até três salá- } \\
\text { rios mínimos }\end{array}$ & - & - & - \\
\hline $\begin{array}{l}\text { Tempo médio de } \\
\text { permanência na } \\
\text { escola }\end{array}$ & 3 anos & 7 anos & - & - & - \\
\hline $\begin{array}{l}\text { Média de habi- } \\
\text { tações atendidas } \\
\text { por rede de } \\
\text { esgoto }\end{array}$ & $0 \%$ & $30 \%$ & $56 \%$ & $52 \%$ & $78 \%$ \\
\hline $\begin{array}{l}\text { Média de } \\
\text { habitações que } \\
\text { possuem água } \\
\text { encanada e } \\
\text { tratada }\end{array}$ & $0 \%$ & $50 \%$ & $69 \%$ & $77 \%$ & $97 \%$ \\
\hline
\end{tabular}




\begin{tabular}{|l|c|c|c|c|c|}
\hline & $\begin{array}{c}\text { Nova Jerusalém } \\
\text { (favela) }\end{array}$ & $\begin{array}{c}\text { Gramacho } \\
\text { (bairro) }\end{array}$ & $\begin{array}{c}\text { Duque } \\
\text { de Caxias }\end{array}$ & $\begin{array}{c}\text { Baixada } \\
\text { Fluminense }\end{array}$ & $\begin{array}{c}\text { Rio de } \\
\text { Janeiro } \\
\text { (capital) }\end{array}$ \\
\hline $\begin{array}{l}\text { Média de habi- } \\
\text { tações ligadas } \\
\text { legalmente à } \\
\text { rede elétrica }\end{array}$ & $0 \%$ & - & - & - & - \\
\hline $\begin{array}{l}\text { Média de habi- } \\
\text { tações atendidas } \\
\text { por coleta regu- } \\
\text { lar de lixo }\end{array}$ & $0 \%$ & $80 \%$ & $89 \%$ & $78 \%$ & $99 \%$ \\
\hline $\begin{array}{l}\text { Afeição ao local } \\
\text { de moradia }\end{array}$ & $0 \%$ & $65 \%$ & - & - & - \\
\hline $\begin{array}{l}\text { Média de mora- } \\
\text { dores maiores } \\
\text { de } 18 \text { anos que } \\
\text { possuem título } \\
\text { de eleitor }\end{array}$ & $30 \%$ & $88 \%$ & - & - & \\
\hline $\begin{array}{l}\text { Média de mora- } \\
\text { dores maiores } \\
\text { de } 18 \text { anos que } \\
\text { votaram nas } \\
\text { últimas eleições } \\
\text { municipais (ano } \\
\text { 2000) }\end{array}$ & $10 \%$ & $75 \%$ & - & - & \\
\hline
\end{tabular}

Os números referentes ao município de Duque de Caxias, ao bairro de Gramacho e à região da Baixada Fluminense ${ }^{15}$ são muito semelhantes, não chamando a atenção as diferenças presentes. Por exemplo: era de se esperar que Gramacho possuísse números referentes ao saneamento básico inferiores àqueles pertencentes ao conjunto a que pertence, que é o município de Duque de Caxias. Estando na periferia do município e sendo densamente povoado, Gramacho destoa dos números oficiais, muito influenciados pelos dados positivos fornecidos pela cidade de Duque de Caxias. É também muito razoável pensar que o município do Rio de Janeiro possua indicadores sociais gerais bastante superiores àqueles presentes na Baixada.

\footnotetext{
${ }^{15}$ Consideramos para a montagem desta tabela os municípios da Baixada Fluminense que possuem um caráter urbano maior. São estes: Nova Iguaçu, Belford Roxo, Mesquita, Queimados, Duque de Caxias, São João de Meriti, Japeri e Nilópolis. Municípios como Guapimirim, Magé, Paracambi etc. não foram considerados porque sua ocupação, mesmo quando antiga, não se desenvolveu na direção da sua transformação em uma área urbana periférica. Mesmo hoje eles são municípios muito semelhantes aos municípios rurais do Estado do Rio de Janeiro.
} 
Enfim, nada nesses números foge ao que se esperaria de uma área periférica da Região Metropolitana do Rio de Janeiro ou de uma favela recente e ainda em formação como Nova Jerusalém. Não é de se estranhar de nenhuma maneira a não existência de fornecimento de água tratada em favelas como Nova Jerusalém, onde tanto a água quanto a energia elétrica utilizadas derivam de ligações clandestinas.

Quando comparamos a média de tempo de permanência na favela com o tempo de residência no bairro de Gramacho, somos surpreendidos não pelo grande tempo que alguém mora em Gramacho, afinal de contas ele é um bairro antigo de Duque de Caxias, tendo começado o seu crescimento demográfico ainda na década de 1940. Surpreendente é o pouco tempo de permanência das pessoas em Nova Jerusalém, revelando a função de área de passagem da favela. Talvez o caráter semiprovisório da habitação em Nova Jerusalém tenha orientado os moradores a sempre responderem negativamente à pergunta "você gosta de morar aqui?". Em Gramacho, cerca de 65\% dos moradores responderam afirmativamente a esse questionamento e metade desses justificaram sua escolha informando que morar em Gramacho é mais seguro do que morar no centro de Duque de Caxias ou em todo o município do Rio de Janeiro.

Apesar do mal-estar dos moradores de Gramacho, é apropositado indagar em que medida tal desconforto deve-se não às diferenças, e, sim, as semelhanças existentes entre esses dois polos aparentemente tão distintos da região da Baixada Fluminense. O caráter estabelecido reivindicado pelos moradores de Gramacho e o consequente preconceito outsider ${ }^{16}$ sofrido pelos favelados do bairro não soam tão estranhos para um visitante de primeira viagem porque a penúria é tão chocante nos casebres de cada uma das favelas que por si somente demonstra as diferenças. Observador radical, entretanto, não consigo ver Gramacho e Nova Jerusalém como lugares sociais tão opostos; antes, representam épocas diversas de um mesmo processo de exclusão popular.

Nas décadas iniciais de assentamento de proletários na Baixada Fluminense, a distância entre os migrantes originais e o poder público era também bastante grande, e a inexistência de qualquer projeto de ocupação popular da região resul-

${ }^{16}$ Utilizo os dois termos inspirando-me na obra de Norbert Elias, Os estabelecidos e os outsiders, Rio de Janeiro, Jorge Zahar, 2000. 
tou no abraço à autoconstrução ${ }^{17}$ como meio de colonização proletária da Baixada e na inexistência de qualquer organização nessa ocupação, o que fez com que o antigo solo destinado à agricultura abrigasse loteamentos, todos irregulares, onde as pequenas casas não se distinguiam demasiadamente dos atuais barracos de Nova Jerusalém:

Aqui, quando a gente chegou, fizemos um quarto só e uma cozinha pequena. Só que naquela época não faltava emprego "pra" ninguém e a meia-água que a gente fez de uma hora "pra" outra devagar foi crescendo. Primeiro era isso aqui que você "tá" vendo. Só esse quarto aqui, porque depois eu arranquei a parede que tinha aqui e juntei cozinha e quarto e fiz essa cozinha de agora. Depois eu fui aumentando devagar, assim quando dava, e depois foi crescendo. Você vê que tem quintal. Dava "pra" ir aumentando e fui fazendo. Agora você vê, a casa é grande e ainda tem filho que fez em cima dela e no quintal também. Ficou todo mundo aqui.

Fatos diferenciadores percebidos pelos habitantes de Gramacho referem-se não exatamente ao processo de construção de habitações nos antigos loteamentos que originaram o bairro. Atuais favelados e pioneiros construtores proletários distinguem-se, sobretudo, porque os favelados de Nova Jerusalém "nunca foram donos de seu teto":

Se você quer saber por que eu acho que eles são assim desse jeito é porque eles não têm nada deles. Eles vivem aqui, mas podia[m] estr em qualquer lugar que não fazia diferença. Eles não têm nada "pra" defender deles. A maior parte nem comprou os "material" do barraco. Eles trabalham onde? Tem um monte de preguiçoso que prefere pedir e ir catar resto de coisa. Outros querem trabalhar, mas não têm força, "tão" doente, "é viciado" na bebida ou coisa pior. A gente aqui tinha um plano quando chegou, trabalhar, construir, economizar, estudar os "filho". Depois que eu aceitei Jesus, então aí é que tudo melhorou mais ainda "pra" mim. Ali não tem nada disso, não. Você vê, são os membros da igreja que me dão mais trabalho aqui, eles lá. Não quer seguir doutrina, não larga vício, cai em pecado toda hora. A gente do ministério aqui nem vai, nem autoriza ninguém de ir mais lá pregar. Eu agora penso assim: a distância de lá até aqui é a mesma que daqui até lá e se o cara quiser aceitar Jesus ele que vem, eu não vou lá buscar alma, não. É uma bagunça e é muito perigoso.

Estar naquele local que "não pertence a ninguém" condicionou os favelados a não serem constantes, não seguirem as regras básicas da religião (doutrina) e a todo momento "se desviarem" e "caírem em pecado" (manterem relações sexuais

${ }^{17}$ Maria Helena Beozzo de Lima, Em busca da casa própria: autoconstrução na periferia do Rio de Janeiro. In: Licia Valadares, Habitação em questão, Rio de Janeiro, Jorge Zahar, 1980. 
não permitidas pelas normas religiosas dessa igreja evangélica). Estender esse descontrole moral para o restante da vida dos favelados, tal como para o pastor Caio, não é difícil para a maioria dos membros de sua igreja, que - quase todos residem em regiões centrais do bairro de Gramacho:

A diferença entre nós e eles? Eles não têm controle de nada. Se eles ganha[m] alguma coisa de manhã, eles come[m] tudo no almoço e fica[m] sem janta, sabe? Falta educação, sei lá. Eles são sujo[s]. Pobreza não quer dizer que tem que ser nojento, não. Uns fede[m] e tudo e não sabe[m] criar filho, não sabe[m] ensinar nada da Bíblia. Não dá exemplo "pra" filho e vive dando mau testemunho "pros" ímpios [pessoas não pertencentes a uma igreja evangélica].

A vida deles não tem ordem. Eles não progridem. Vive[m] só da ajuda dos outro, e isso "pra" mim quer dizer que eles não se converteram de verdade, porque a palavra de Deus diz que justo não mendiga pão, e eles vivem de resto da gente. Aí a vida deles não é abençoada. Eles vivem com doença e sem emprego e acaba[m] sendo mexido[s] por vagabundo de lá de dentro.

Na memória dos moradores de Gramacho, a lembrança de suas maneiras de "construir o bairro" ao longo das últimas décadas parece ser o fator responsável pelo preconceito contra os favelados, sendo a propriedade do lote, a construção de uma casa e a organização do espaço público - "não chamava a atenção de nenhuma autoridade, que nunca fez nada de verdade 'pra' cá a não ser há pouco tempo" - fatores determinantes de uma "vida decente" e arcabouço de algo valorizado ao extremo pelos "trabalhadores". Algo que se expressa na última fala como "ordem". Traduzo isso como um anseio capital na vida de um morador periférico, porque possibilitador de que as situações adversas sofridas pelos colonizadores migrantes pioneiros, tanto em suas vidas anteriores em outros locais do Brasil quanto em sua nova vida nos loteamentos da Baixada Fluminense, não se repitam na atualidade:

Se você tem uma vida desorganizada, sua vida não melhora nunca. Você precisa de ordem na sua vida. Sua vida tem que ser de trabalho. Você precisa ter profissão, precisa ter casa "pra" não ter que viver no aluguel, senão você acaba se viciando, virando homem que não sai de barraca, gastando dinheiro à toa. Você pode ver que quem não tem família, não tem religião não consegue arranjar emprego direito, vira viciado, se mete com bandidagem. O homem tem que ter ordem na vida dele. Aqui, se você não for equilibrado na sua vida, você se dá mal e você estraga a vida também da sua família toda. Você vê só, eu não estudei nunca, eu nem sei ler, eu só sei assinar o nome, e muito mal. Mas eu, quando vim "pra" cá lá do Norte, eu vi que tinha que bata- 
lhar muito até começar a trabalhar de motorista de ônibus. Aí eu fui melhorando, e a mulher foi ajudando muito também, e aí a gente deu uma vida melhor "pra" os meninos. Você vê, os três faz[em] faculdade, e tudo faculdade federal. Todo mundo trabalha e não tem vício. Você vê, se eu fosse um homem de porta de barraca que não trabalha, que não tem profissão, isso ia dar "pra” ser assim? Eu mesmo já vi aqui muito homem morrer em porta de barraca brigando por causa de nada e largando a família desamparada aí.

Para os moradores de Nova Jerusalém, essa ordem familiar não é algo acessível devido à própria insegurança de suas vidas, imersas em uma pobreza extrema, que fez um líder comunitário local visualizar a favela como o retrato de Gramacho na época em que chegou do interior do Espírito Santo, não possuindo absolutamente nada e precisando se virar no bairro que "não tinha nada" e ao lado de uma grande quantidade de gente que vinha principalmente do Nordeste:

Sabe, o povo de Gramacho devia lembrar mais do passado e não ver essas comunidades pobres daqui como coisa do outro mundo. Nova Jerusalém é a Gramacho de amanhã, porque Gramacho, quando começou, era igual [a] Jerusalém! É besteira esse negócio de sacanear quem mora lá só porque é favela, porque isso aqui é uma coisa só, e os políticos tratam a gente aqui igual trata[m] eles lá. Você "ta" vendo aqui tudo asfaltado, mas é só aqui, que é centro, aí "pra” trás e lá "pra” dentro é tudo sem asfalto, esgoto, pouco colégio, sem posto de saúde. É tudo igual [a] Jerusalém, só que é bairro. Eu não acho que tem razão isto, não. Esse povo daqui tem orgulho não sei de quê.

A opinião do líder comunitário destoa das demais, porque visualiza seu bairro e as favelas, que chama de "Jerusalém", como algo semelhante, além dos outros moradores, que procuram as distâncias estabelecidas pela visível penúria dos habitantes dos casebres que margeiam o rio Sarapuí. Eminentemente, suas opiniões levam em consideração a pequena presença estatal no bairro e nivela os dois locais de moradia proletária apontando para o fato de que obras públicas executadas ali somente surgiram há pouco tempo e derivaram dos interesses de um novo tipo de político que passou a existir na Baixada Fluminense durante a década de 1990 e que representou a subida ao poder de pessoas originariamente pertencentes às classes populares, responsáveis pelo auxílio à população na resolução de problemas que nasceram no momento de chegada dos migrantes 
à região da Baixada Fluminense e que se complexaram na mesma proporção em que a população da região aumentava. ${ }^{18}$ Mas essa é outra história.

${ }^{18}$ Exemplo de trabalho que apresenta pesquisa ainda em andamento sobre a trajetória de líderes populares nas cidades da Baixada Fluminense pode ser encontrado em Linderval Augusto Monteiro, Andando pelo vale da sombra da morte: a trajetória política de Joca, primeiro prefeito de Belford Roxo, Revista Universidade Rural, Série Ciências Humanas, v. 29, p. 55-71, 2007. 